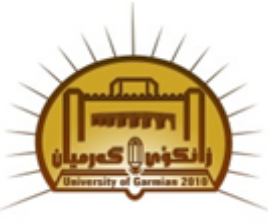

Available online at http://jgu.garmian.edu.krd

Journal of University of Garmian

https://doi.org/10.24271/garmian.196361

\title{
The Aftermath of the Armenian Genocide and the Holocaust: A Comparative Study
}

\author{
Dlpak Jabar Ali Dawoodi \\ Department of History, College of Education, University of Garmian
}

\section{Article Info}

Received: August, 2019

Revised:August,2019

Accepted:September,2019

\section{Keywords}

Genocide, modern history, Armenian and the Holocaust

Corresponding Author

Dlpak.jabar@garmian.edu.krd

\section{Abstract}

In the era of twentieth century, most of chemical attacks and mass killings happened; the Armenian genocide and the Holocaust were two of them. These two genocides led to the deaths of about seven million people. The first genocide of 20th century was Armenian genocide which was done by the Ottoman Empire, Three decades later another genocide happened by Hitler regime against the Jews from 1939 to 1945.

This topic still demands attention from historians to analyze the effects of these mass killing of the nations and pass them to the new generation. There are a number of similarities and differences between the aftermaths of these two genocides. This paper analyses the situation of both genocides after the first and second world wars, and discusses the attitudes of the Allies for each event. It also focuses more on the aftermath of both nations. The aim is to compare the aftermath of the Armenian genocide and the Holocaust in terms of trials, denials and reparations.

\section{Introduction}

The twentieth century is sometimes called the century of genocide, because most of history's mass killings happened in this century. One of the first genocides of modern history was the Armenian genocide, which took place in the early twentieth century. (1 p. 94) It was prepared by the Ottoman government under the direction of the Committee of Union and Progress (CUP) during the First World War, and resulted in the massacre of the Armenians of eastern Anatolia Most of the boys and men were killed, and others were deported to the deserts of Syria and Iraq. (1 p. 1) This led to the deaths of around one million Armenians in their historic homeland. (2 p. 231)

A quarter of a century later another genocide occurred during the Second World War, which is known as the Holocaust. About six million Jews were killed by the Nazi regime between 1939 and 1945 in the deadliest genocide of the twentieth century. These genocide alerted the victorious countries to act to prevent more genocides from taking place. It was the responsibility of the victors to punish the perpetrators of genocide after the two World Wars. 
There are a number of similarities and differences between the aftermaths of these two genocide. This article will analyse the situation of both genocides after the world wars, and discuss the attitudes of the Allies and how they punished those who were responsible for each event. It will examine how the nations of the world confronted such an atrocity. It will then compare the cases of the Armenians and the Jews through international effort. Finally, the paper will compare the aftermath of the Armenian genocide and the Holocaust in terms of trials, denials and reparations.

\section{The Term Genocid}

Until 1948 there was no name for the crime we call genocide. As Winston Churchill said, "genocide was a crime without a name". (3 p. 8) The term 'genocide' was coined by Raphael Lemkin (1900-1959), a Polish-Jewish lawyer and a refugee from Nazi-occupied Europe. (3 p. 8) He created the word 'genocide' by combining geno-, from the Greek word for race or tribe, with -cide, from the Latin word for killing. (4 p. 297) The term refers to serious crimes committed against a group of people in order to destroy them.

In proposing this new term, Lemkin had in mind "a coordinated plan of different actions aiming at the destruction of essential foundations of the life of national groups, with the aim of annihilating the groups themselves". (5) While humans have been wiping out other groups of humans since antiquity, Lemkin was the first to create a word for this activity: 'genocide'. His work Axis Rule in Occupied Europe provided evidence for this term, and used it to examine events of the Second World War in Germany, Poland and other regions controlled by the Nazis. The UN later created a convention on the crime of genocide, which was largely due to the efforts of Lemkin. (3 p. 8)
The Role of the Allies in dealing with the aftermath of the Armenian genocide and the Holocaust

After defeating the Ottoman Empire in the First World War, the surviving Armenians were present with an opportunity to advance their national self-determination. At the same time, the Allies wondered how to deal with the events that happened after the war in the Middle East at the political and legal levels. Initially, the most important point was 'obtaining guarantees that there would be no future massacres, particularly in the eastern provinces of Asia Minor and the Caucasus'. (6 p. 763) Moreover, the American President Woodrow Wilson granted the Armenian nation the right to delimit a new Armenian independence. (6 p. 166) The American stance was different from the British and Germany policies towards Turkey after the First World War, because the Americans did not benefit economically from the Ottoman Empire. (7 p. 29)

Furthermore, according to Jay after the First World War the United States assisted the victims of the Armenian genocide diplomatically and humanitarianly. There was a great possibility that the United States "would serve in one form or another as a protector and 'big brother' of an emerging Armenian state and perhaps the surrounding territories as well". (8 p. 257) One of the stronger recommendations among the American intelligence division's post war time was the creation of an Armenian state under the protection of 'a mandatory power serving under the aegis of the soon-to-be-formed League of Nations'. (8 p. 259) The American intelligence division wrote:

The principle of majorities should not apply in this case, because of the conditions under which the Armenian people have lived in the past. They have suffered from every handicap of nature and man; they have been massacred and deported by hundreds of thousands; they have been subject of international political intrigue; 
and at this moment, helpless and weak as they are, they are being pressed for the unfavourable settlement of their affairs by big Powers seeking to define spheres of future political and commercial interests. It would be a departure from the principle of fair dealing if at this time their every claim were not heard with patience, and their new state established under conditions that would in some manner right historic wrongs. (8 p. 259)

After the catastrophe, America decided to grant Armenia its independence, and Congregational ministers in American defended Armenian independence. President Wilson was disinclined to pressure Congress into allowing him to accept any obligations for Armenia, even though the idea had been received favourably. He was also unwilling to provide the resources needed to defeat the Turkish armies occupying the area of the planned nation of Armenia, or to repatriate the remaining survivors of the Armenian genocide. (8 p. 260)

However, these attempts to salvage Armenia were unsuccessful because the creation of the Turkish national movement by Mustafa Kemal in 1923 resulted in the creation of the Turkish Republic. No action was taken against Turkey to be penalised for its crimes against the Armenians, despite the moral outrage of the international community. In addition, it was too late to resolve the issues between the groups by withdrawing from Turkey, although the Americans might be correct in their belief that these difficulties were caused by the iniquities of the powers. ( 7 p. 30) Bloxham therefore concludes that:

Both powers arrived in eras of Armenian massacre, both were seeking a foothold in an economy dominated by other powers, with Russia a looming political influence to the northeast, both used their indifference towards the fate of the Armenians as a bargaining tool to gain advantage with the Turkish government while other powers were proactively manipulating the Armenian question in their own interest, and neither shrank from misrepresenting the Armenian plight to their own ends. (1 p. 206)

After the Second World War, the international response to the Nazis' crimes against the Jews was much stronger than the international response in the Armenian genocide. The UN General Assembly adopted Resolution 96 (I) on 11 December 1946, which includes the phrase "offense against human rights". (6 p. 774) The 1919 Committee on Responsibility led to the 9 December 1948 Genocide Convention, and indeed many parts are similar. For example, Article 3 of the 1948 convention defines the types of perpetrators of genocide similarly, while Article 4 states that anyone involved in the genocide at any level should receive a criminal trial. Article 6 also calls for the creation of an international court similar to that described in the 1919 report. (6) The 1919 committee's suggestions regarding crimes which violate human rights were ignored at the time, but the United Nations ended up using them in the aftermath of World War Two. It appears that the decisions to punish the Nazis for the Holocaust were inspired by the Allies' failure to create an international court following World War One. (6)

Additionally, the United States created a state for the Jews outside of Europe where they could start a new life. This state was created in Palestine, where the original Jewish state was located, and it was the destination of the Jewish survivors. (5) Moreover, in the aftermath of the Holocaust between 1945 and 1951, the United States played an important role in guarding over one million displaced persons in the occupied zones of Germany, Austria, Italy, and Czechoslovakia. Moreover, the American President Harry S. Truman supported Jewish immigration. (5)

Moreover, there were several differences in international attitudes towards the Armenian 
genocide and the Holocaust. The crimes that the Ottoman Empire had committed against the Armenians in the First World War went unpunished, while most of the perpetrators of the Holocaust paid the penalty for their crimes because of an international court. Furthermore, the state of Israel was created for the Jews in 1948, while "The treaty of Lausanne in 1923 contained no provision for rehabilitation, restitution or compensation for the Armenians and marked the final allied abandonment of the Armenian question". (9 p. 15)

Finally, the international arena also needs to be reviewed. Peace treaties were never established between the major enemy states and the Allied nations. Therefore, they never settled their postwar dealings with their former opponents. (10 p. 94) Indeed, the Second World War ended with the beginning of the Cold War, as the former Allies could not agree on how Germany should be run following the end of the Nazi regime. The division of the nation into East and West Germany amid a set of raucous and fruitless meetings which saw the Allied relationships sputter out and hostility take hold (10).

\section{The Armenian genocide and the Holocaust} trials

The Turkish court-martial of 1919-20 occurred during the aftermath of the First World War. It sentenced the leadership of the Committee of Union and Progress to death for wartime profiteering, and for the massacres of both the Armenians and the Greeks. Among those sentenced to death were Enver Pasha (Minister of War) and Talaat Pasha (Minister of Interior), who were responsible for ordering the Armenian genocide. (11 p. 10) Additionally, the "Treaty of Se'vres included a provision that demanded from the Ottoman government the surrender of persons who committed massacres during the war, in order that they be tried before a tribunal created by the League of Nations". (12 p. 106)
However, the perpetrators of the Armenian genocide who had been sentenced to death escaped, because at that time there were no international laws in place under which they could be tried. Although the British administration tried to continue the trials on the Armenian genocide, the Turkish National Movement and their blackmail "forced the British government to release the prisoners it held at Malta and Mudros". (12) Moreover, in 1923 the new Turkish government pardoned those who had been sentenced. As a result, the Armenian atrocities were forgotten (Segesser, 2008, p. 106). The British position was therefore criticized. Moreover, during the convention on the punishment and prevention of genocide in New Haven in 1949, Lemkin declared that "it was only after the extermination of 1,200,000 Armenians during the First World War that the victorious Allies promised to the survivors of this abominable massacre an adequate law and a court. But that did not happen". (6 p. 774) He blamed the Allies because they "had not carried their logic through to the end", so the offense against the Armenians had gone unpunished.

On the other hand, the situation following the Second World War was very different from that of the First World War. According to International Military Tribunal at Nuremberg at the end of the Second World War, the leaders of the United States, the United Kingdom, France and the Soviet Union declared on December 17, 1942 that they would punish the major war criminals of the Axis Powers, officially recognise the mass murder of the European Jews, and 'prosecute those responsible for violence against civilian population'. (5) As a result, the Allies decided to engage an International Military Tribunal (IMT) 'so that the Germans would not be able to claim that an admission of war guilt was extracted from them under duress'. (5) Additionally, the IMT trial at Nuremberg was one of the most famous of the criminal trials to take place after the Second 
World War. Between 1945 and 1949, 13 trials were completed in Nuremberg. Most of the defendants had participated in the crimes of the Nazis and were accused of crimes against humanity and against peace. As in the Armenian case, some perpetrators of Nazi-era criminality were not punished for their crimes. (5) Nevertheless, this does not mean that the perpetrators of the Holocaust were not punished like the perpetrators of the Armenian genocide. In summary, the Holocaust led to the formation of international courts and the trial of the perpetrators. In the Armenian case, the defendants did not face any penalty for their crimes. It could be argued that the Armenian genocide aftermath as a first genocide in twenty century experienced Allies to deal with the German crimes in an international framework.

The Armenian genocide and Holocaust denial After the First and Second World Wars, denial of genocide was considered as a phenomenon. This aims to minimize or deny any declaration that genocide occurred. In the Armenian case, denial played a great role by attacking the true representation of the past. Bloxham states that "denial also emerged with the genocide itself". (1 p. 111) After the First World War, the Turkish government denied the occurrence of Armenian genocide. The Turkish government has gone to great efforts to prevent any debate about the Armenian genocide from taking place in the social studies curriculum. (13 p. 4)

Furthermore, in the 1980s the Turkish government supported the creation of the Institute of Turkish Studies, which aimed to further the denial of the 1915 genocide in their research into Turkish history and culture. (13) Hovannisian claims that denial is more advanced in the Armenian situation, and that it obtained a footing in the mainstream historical profession. (9 p. 202) Denial has progressed much further as regards the Armenian genocide, and has been adopted by a number of historians However, denialists have gone from completely denying that the genocide occurred to trivializing, rationalizing and relativizing it instead. This strategy is intended to make it appear that there is controversy over the events which took place, and make it appear that what some have termed genocide has just been taken the wrong way and distorted. They accuse the survivors of being con-men looking to make a quick buck, and dismiss any evidence of wrongdoing as old military propaganda designed to turn the public against them at a time of war. (9 p. 201)

The same strategy is not used in the Holocaust denial. The Holocaust is part of historical discussion, especially in Germany. This makes some scholars tensional of the Holocaust. This is because "those who place the holocaust in the context of human victimology trivialize the enormity of the events by pointing to the repeated violence and mass destruction in the twenty century". (9 p. 202)

On the other hand, there are some differences in the treatment of the Armenian genocide and the Holocaust. According to Jonassohn, one main difference is that:

The Holocaust literature directed at remembering, understanding, and preventing a recurrence by emphasizing the role of human rights, while much of the literature on the Armenian genocide still addressed matters of historical fact almost three-quarters of a century after the events of 1915. Another difference is that German authors are participating in the examination of what happened, whereas Turkish authors are still trying to deny that genocide occurred. (9 p. 203)

Furthermore, denial strategies are not used equally in every case. For example, some Holocaust denialists argue that the Holocaust was feigned by the Jews to advance their interests and to recognize their separation in the Germany and Europe. (14) However, the denialists in the Armenian case try to deny the Armenian genocide by influencing history and 
culture to decrease the Armenian entity in the area. Finally, according to Hovannisian, denialists and rationalizers of both the Armenian genocide and the Holocaust argue that:

1. Stories about alleged genocide are based on wartime propaganda.

2. Armenians in the Ottoman Empire and Jews in Europe were perceived as posing very real security threats, and their actions demonstrated that these concerns were not imaginary.

3. There was no intent to annihilate either group, only to relocate its members.

4. The deaths that occurred were primarily from the same causes that carried away even more Turks and Kurds in the Armenian case, and Germans in the Jewish case.

5. The number of Armenian and Jewish death is much less than claimed, and most of the alleged victims actually ended up in other countries.

6. The myth of genocide was created in both cases for economic and/or political motives.

7. Those who believed and promoted the myth have been the wilful or unwitting abettors of communism and Soviet expansion and the destabilization of the NATO alliance and the West.

8. The proponents of truth - that is, those who do not accept the reality of genocide against the Armenian people - are struggling against powerful political lobbies to rectify negative stereotypes and historical misconceptions as persons brave and bold enough to champion free speech and inquiry. (9 p. 205)

\section{Reparations for the Armenian genocide and} the holocaust

Reparations are an important way for victims to recover their economic viability, physical survival and political security. A reparation plan for the Armenian genocide was advanced as part of the Paris peace treaty after the First World War. Additionally, the Armenian revolutionary federation has demanded reparations in the form of territorial claims from Turkey ever since the Armenian genocide took place. (15 p. 2) Nevertheless, "nothing has been done by the Turks in the way of repatriation of Armenians or of reparations to them". (8 p. 264) so the Armenians have "never received the reparations due them". (15 p. 1)

By way of contrast, after the Second World War the Jewish Agency made a formal claim of reparations to the four countries that controlled Germany: the United States, Great Britain, France and the Soviet Union. The Agency argued that Germany had to pay financial reparations for the resettlement of Holocaust survivors. (16) The first request for reparations appeared in 1948, when Israeli Ministr of Finance Eliezer Kaplan raised the request presented to him by an all-Jewish committee on dealing with the issue of Jewish property expropriated during the Holocaust. (17)

As a result, the Jews obtained financial reparations for Jewish suffering and were reimbursed for the possession stolen by the Nazis. Attempting to redress the crimes of the Holocaust, West Germany paid hundreds of millions of dollars to the Israeli state between 1953 to 1965 for Jewish survivors and German refugees. (16) For example, in 1951 West Germany paid $\$ 55$ billion to four million holocaust survivors and the Israel state. In contrast, East Germany stated that the Holocaust was the crime of the Nazis, not the Germans, and did not give anything to the Holocaust survivors. (18)

Transnational memory of the Armenian genocide and the Holocaust

The Armenian genocide represented the systematic destruction of an entire people, and was followed by a persistent campaign of denial. This actuated the Armenians "in their search for a sense of home". (19 p. 95) As Goekjian has claimed، 
Put simply, the Holocaust constituted a symbolic end to the Jewish diaspora, whereas the Genocide is the symbolic origin of the Armenian diaspora: in actuality, of course, an enormous and powerful Jewish diaspora remains after the Holocaust, and Armenia had a significant diaspora for centuries before the Genocide. But whereas the Holocaust resulted in the creation of a concentrated, modern centre for Jewish historical discourse, the Armenian Genocide erased that centre, creating a 'nation' that has had to exist in exile and memory -in diaspora. (19 p. 97)

Following the collapse of communism and while Eastern European nations were normalizing their relationships with the West, Holocaust memories began to be Europeanized. This process began as the ex-communist nations sought entry into NATO and the European Union, amongst other bodies, and carried on after they had been successful (20 p. 99) .

Gemany and Turkey in dealing with genocide The aftermaths of the Turkish and German genocide cases were handled very differently. First, Germany accepted that the Holocaust was genocide. Moreover, Germany supported the international trials prepared by allies at Nuremberg and Frankfurt, as well as the Eichmann trial. By recognizing genocide occurred, Germany accepted its history and faced its own past fairly. (21 p. 92)

On the other hand, "Turkey has not recognized its own genocide of the Armenians" and the use of the term genocide to refer to the Armenian issue in Turkish history is illegal. To this day, the Turkish government continues to reject the idea that the massacre of the Armenians was genocide. (21 p. 97) In 2004 Erdogan, Prime Minister of Turkey, stated that "Turkey does not bother about the Armenian genocide. Genocide allegations are to be resolved by historians, not parliaments". (21 p. 96) Additionally, compared to Germany there are few memorials, archives and museums in Turkey which recall the Armenian genocide. Besides most of the evidence related to the genocide has been destroyed by the Turkish government. Meanwhile the Armenian state borders Turkey, but there is no relationship between them.

\section{Conclusion}

In conclusion, this study has discussed some similarities and differences between the aftermath of the Armenian genocide and the Holocaust. The allies did not bring the perpetrators of the Armenian genocide to justice, and hopes for an Armenian state were dashed after the Treaty of Lausanne due to Turkish nationalism. Meanwhile, in the aftermath of the Holocaust the Jews obtained their own state in 1948, and most of the perpetrators were punished for their crimes by an international court created by the allies. It can be said that the allies abandoned the Armenians after the First World War, but they did not abandon the Jews after the Second World War.

This article has shown how the process of denial happened in both genocides, and that the same denial strategy was used in both. However, the Armenian survivors did not obtain any reparations from the Turkish government while surviving Jews have received reparations along with the Israeli state.

\section{References}

1. Bloxham, Donald. The Great Game of Genocide. Oxford : Oxford University Press, 2009.

2. The Case of an Armenian Mass Grave. Croft., Roxana Ferllini \& Alexandra M. 3, s.l. : Journal of Human Rights, 2009, Vol. 8.

3. Jones, Adam. Genocide A Comprehensive Introduction. Florence : US: Routledge, 2010.

4. Prologue: The Man Who Made Genocide a Crime: The Legacy of Raphael Lemkin. Goldman, Stanley A. 3, s.l. : Loyola of Los Angeles International and Comparative Law Review, 2011-2012, Vol. 34. pp. 295-300. 
5. International Military Tribunal at Nuremberg. Holocaust Encyclopedia. [Online] United States Holocaust Memorial Museum. [Cited: 12 April 2016.] www.ushmm.org.

6. Kevorkian, Raymond. The Armenian Genocide: a complete history. London : GB: I.B.Tauris, 2011.

7. Bloxham, Donald. Genocide, the world wars and the unweaving of Europe. London : Vallentine Mitchell, 2008.

8. Winter, Jay. America and the Armenian Genocide of 1915. Cambridge : Cambridge University Press, 2004.

9. Hovannisian, Richard G. Remembrance and denial: The case of the Armenian genocide. Wayne State : University Press, 1998.

10. The Past is Another Country: Myth and Memory in Postwar Europe. Judt, Tony. 4, s.l. : Daedalus, 1992, Vol. 121. pp. 83-118.

11. Gunter, Michael M. Armenian History and the Question of Genocide. [Online] Palgrave Macmillan, 2011. [Cited: 29 March 2016.] http://www.palgraveconnect.com.ezproxy3.lib.le .ac.uk/pc/doifinder/10.1057/9780230118874.

12. 'Dissolve or punish? The international debate amongst jurists and publicists on the consequences of the Armenian genocide for the Ottoman Empire, 1915-23. Segesse, Daniel Marc. 1, s.l. : Journal of Genocide Research, 2008, Vol. 10. pp. 95-110.

13. Professional ethics and the denial of Armenian genocide. Roger W Smith, Eric Markusen, and Robert Jay Lifton. 1, s.l. : Holocaust and Genocide Studies, 1995, Vol. 9. pp.1-22.

14. Holocaust Denial and Distortion. United States Holocaust Memorial Museum. [Online] Holocaust Encyclopedia. [Cited: 25 April 2016.] https://www.ushmm.org/confront-

antisemitism/holocaust-denial-and-distortion.

15. Introduction: the global reparations movement. Theriault, Henry C. 1, s.l. : Armenian Review, 2012, Vol. 53.

16. Reparations and Restitutions. resource center. [Online] [Cited: 24 July 2018.] http://www.yadvashem.org/yv/en/holocaust/reso urce_center/item.asp?GATE $=$ Z\&list_type $=2$ -

60\&type_id $=5 \&$ total $=$ Y.

17. Sharett, Yaakov. The Reparations Controversy. Berlin/Boston : DE: De Gruyter, 2011.
18. Exploiting the Holocaust. Morse, Martin. 1, s.1. : The American Enterprise , 2001, Vol. 12.

19. De Cesari, Chiara, and Rigney, Ann,. Transnational Memory. (Berlin/Boston : De Gruyter, 2014.

20. The Europeanization of Holocaust Memory and Eastern Europe. Kucia, Marek. 1, s.l. : East European Politics \& Societies, 2016, Vol. 30. pp. 97-119.

21. Richards, Allison. Foreign Policy and the Aftermath of Genocide. Vienna : Austria, 2007.

\section{Bibliography}

1. Balakian, P. (2013). Raphael Lemkin, Cultural Destruction, and the Armenian Genocide. Holocaust and Genocide Studies, 27(1), pp.57-89.

2. Bloxham, D. (2008). Genocide, the world wars and the unweaving of Europe. London: Vallentine Mitchell, pp. 29-33.

3. Bloxham, D. (2009). The great game of genocide. Oxford: Oxford Univ. Press, pp. 94206.

4. cesari, CH. \& Rigney, A. (2014). Transnational Memory. Berlin/Boston: DE: De Gruyter, p. 95.

5. Dumančić, M. (2015). Myth, Memory, Trauma. Rethinking the Stalinist Past in the Soviet Union, 1953-70. Europe-Asia Studies, 67(3), pp.494-496.

6. Engage.ushmm.org. (2019). United States Holocaust Memorial Museum. [online] Available at: https://engage.ushmm.org/support.html [Accessed 19 Feb. 2019].

7. Ferllini, R. and Croft, A. (2009). The Case of an Armenian Mass Grave. Journal of Human Rights, 8(3), pp.229-244.

8. Gunter, M. (2011). Armenian History and the Question of Genocide. [ebook] New York: Palgrave Macmillan. Available at: http://www.palgraveconnect.com.ezproxy3.lib.le .ac.uk/pc/doifinder/10.1057/9780230118874

[Accessed 16 Feb. 2019].p. 10.

9. Henry, T. (2012). Introduction: the global reparations movement. [online] Go.galegroup.com.ezproxy4.lib.le.ac.uk.

Available at: http://go.galegroup.com.ezproxy4.lib.le.ac.uk/ps /i.do?id=GALE\%7CA317901857\&v=2.1\&u=lei cester\&it=r\&p=EAIM\&sw $=w \& a s i d=c 029 b 4183$ 
ac5c50ca5302957efd5601e [Accessed 19 Feb. 2019].

10. Hovannisian, R. (1998). Remembrance and denial. Wayne State: University Press, p.15.

11. Jones, A. (2010). Genocide A Comprehensive Introduction, Florence, US: Routledge, p. 8.

12. Judt, T.(1992). The Past is Another Country: Myth and Memory in Postwar Europe', Daedalus, 121(4), pp. 83-118.

13. Kévorkian, R. (2011). The Armenian genocide. London: I.B. Tauris, pp. 763- 774.

14. Kucia, M. (2016). The Europeanization of Holocaust Memory and Eastern Europe. East European Politics \& Societies, 30(1), pp.97-119.

15. Miller, Documents, vol. IV, pp. 25960. (cited in Winter, Jay, (ed.), America and the Armenian Genocide, p. 259.

16. Morse, M. (2001). Exploiting the Holocaust. [online]

Go.galegroup.com.ezproxy4.lib.le.ac.uk.

Available at: http://go.galegroup.com.ezproxy4.lib.le.ac.uk/ps /i.do?id=GALE\%7CA69974530\&v=2.1\&u=leic ester \&it=r\&p=EAIM \&sw=w\&asid=a7016bc50f 7d42d65b2bab534958989b 2 [Accessed 19 Feb. 2019].

17. Richards, A. (2007). Foreign Policy and the Aftermath of Genocide. Vienna, Austria, p. 92.

18. Segesser, D. (2008). Dissolve or punish? The international debate amongst jurists and publicists on the consequences of the Armenian genocide for the Ottoman Empire, 1915-23. Journal of Genocide Research, 10(1), pp.95-110.
19. Sharett, Y. (2011). The Reparations Controversy. Berlin/Boston: DE: De Gruyter, p. 12.

20. Smith, R., Markusen, E. and Lifton, R. (1995). Professional Ethics and the Denial of Armenian Genocide. Holocaust and Genocide Studies, 9(1), pp.1-22, (p. 4).

21. Stanley, A. (2012). Prologue: The Man Who Made Genocide a Crime: The Legacy of Raphael Lemkin. Loyola of Los Angeles International and Comparative Law Review, 34(3), pp. 295-300.

22. Ushmm.org. (2019). What is Genocide?. [online] Available at: https://www.ushmm.org/wlc/en/article.php?Mod uleId=10007043 [Accessed 16 Feb. 2019].

23. Ushmm.org. (2019). Holocaust Denial and Distortion. [online] Available at: https://www.ushmm.org/confrontantisemitism/holocaust-denial-and-distortion [Accessed 19 Feb. 2019]. 24. Ushmm.org. (2019). What is Genocide?. [online] Available at: https://www.ushmm.org/wlc/en/article.php?Mod uleId=10007043 [Accessed 19 Feb. 2019].

25. Winter, J. (2004). America and the Armenian genocide of 1915. Cambridge: Cambridge Univ. Press, pp.250-265(p.257).

26. Yadvashem.org. (2019). Reparations and Restitutions. [online] Available at: http://www.yadvashem.org/yv/en/holocaust/reso urce_center/item.asp?GATE $=$ Z\&list_type $=2$ 60\&type_id=5\&total=Y [Accessed 19 Feb. 2019]. 